\title{
Interpretation of concurrent positive skin tests to prophylactic antibiotics and rocuronium
}

\author{
Kazuhiro Nagumo ${ }^{1}$, Tomonori Takazawa ${ }^{2^{*}}$ (D) and Shigeru Saito ${ }^{1}$
}

To the Editor,

We read with great interest the article by Yasuda et al. on concurrent positive skin tests to prophylactic antibiotics and rocuronium in two patients [1]. The authors hypothesized the possible synergistic effect of antibiotics and neuromuscular blocking agents (NMBAs) on anaphylactic reactions. As evidence to support their hypothesis, they quoted a previous study that showed that patients with positive skin tests to antibiotics were more likely to have positive skin tests to NMBAs [2]. However, we believe that the evidence to prove their hypothesis is insufficient for the reasons described below.

First, since the authors did not indicate the concentration of drugs being tested when the skin test was positive, the possibility of false-positive skin test results cannot be ruled out. In general, false positives should be kept in mind when skin tests are positive, especially when they are positive for two or more drugs. NMBAs, in particular, are well known as drugs that are prone to producing false-positive results. Adherence to the maximum concentrations of drugs recommended in the guidelines is crucial to avoid false-positive results in skin testing [3]. Further, lack of information on both the method of determining the positive skin test and photographs of the skin test results is another reason why we suspect there could have been false-positive results in these two cases.

Next, it is possible that case 2 might not even have developed anaphylaxis, since other possible causes can explain the observed decrease in blood pressure and percutaneous oxygen saturation $\left(\mathrm{SpO}_{2}\right)$ : hypotension might have occurred secondary to the effect of epidural

\footnotetext{
* Correspondence: takazawt@gunma-u.ac.jp

Intensive Care Unit, Gunma University Hospital, 3-39-15 Showa-machi,

Maebashi, Gunma 371-8511, Japan

Full list of author information is available at the end of the article
}

anesthesia and anesthesia-inducing drugs. Since a decrease in $\mathrm{SpO}_{2}$ occurs after pneumoperitoneum, the cause for decrease in $\mathrm{SpO}_{2}$ could likely have been atelectasis due to elevation of the diaphragm. Additionally, no increase in serum tryptase was observed. Applying the clinical score of perioperative anaphylaxis to case 2 gives a total of 6 points: 6 points for severe hypotension, 2 points for a poor response to the standard dose of sympathomimetics, 3 points for the onset of cardiovascular features within $15 \mathrm{~min}$ of a possible intravenous trigger (including our estimates), - 1 point for neuraxial regional anesthesia, and -4 points for absence of tryptase elevation [4]. A score of less than 8 is defined as "unlikely to be an immediate hypersensitivity reaction", suggesting that case 2 was not anaphylaxis [4]. Further, the cut-off value for serum tryptase mentioned by the authors $(5.7 \mathrm{ng} / \mathrm{ml})$ is different from the cut-off value that is generally used $(11.4 \mathrm{ng} / \mathrm{ml})$. Alternatively, basal tryptase $\times 1.2+2 \mathrm{ng} / \mathrm{ml}$ is the recommended gold standard threshold in evaluating mast cell activation [5].

In summary, the authors' hypothesis is promising and worth investigating. However, their claim that both cases represented anaphylaxis cases with positive skin tests to muscle relaxants and antibiotics might not be correct for the reasons given above. We recommend the combined use of in vitro tests with high specificity, for example, the basophil activation test, when skin tests show ambiguous results, including positivity for multiple drugs.

\author{
Abbreviations \\ NMBA: Neuromuscular blocking agent; $\mathrm{SpO}_{2}$ : Percutaneous oxygen \\ saturation
}

Springer Open (c) The Author(s). 2021 Open Access This article is licensed under a Creative Commons Attribution 4.0 International License, which permits use, sharing, adaptation, distribution and reproduction in any medium or format, as long as you give appropriate credit to the original author(s) and the source, provide a link to the Creative Commons licence, and indicate if changes were made. The images or other third party material in this article are included in the article's Creative Commons licence, unless indicated otherwise in a credit line to the material. If material is not included in the article's Creative Commons licence and your intended use is not permitted by statutory regulation or exceeds the permitted use, you will need to obtain permission directly from the copyright holder. To view a copy of this licence, visit http://creativecommons.org/licenses/by/4.0/. 


\section{Authors' contributions}

All authors contributed to writing the manuscript and approved the final manuscript.

\section{Funding}

This study was supported by JSPS KAKENHI grant number 20 K17829.

Availability of data and materials

Not applicable.

\section{Declarations}

Ethics approval and consent to participate

Not applicable.

\section{Consent for publication}

Not applicable.

\section{Competing interests}

The authors declare that they have no competing interests.

\section{Author details}

'Department of Anesthesiology, Gunma University Graduate School of Medicine, Gunma, Japan. Intensive Care Unit, Gunma University Hospital, 3-39-15 Showa-machi, Maebashi, Gunma 371-8511, Japan.

Received: 20 July 2021 Revised: 20 July 2021

Accepted: 16 August 2021 Published online: 23 August 2021

\section{References}

1. Yasuda M, Moriwaki K, Tsutsumi YM. Concurrent positive skin tests to prophylactic antibiotics and rocuronium in two patients with lifethreatening anaphylaxis after induction of anesthesia. JA Clin Rep. 2021;7(1): 37. https://doi.org/10.1186/s40981-021-00440-0.

2. Hagau N, Gherman N, Cocis M, Petrisor C. Antibiotic-induced immediate type hypersensitivity is a risk factor for positive allergy skin tests for neuromuscular blocking agents. Allergol Int. 2016;65(1):52-5 https://doi. org/10.1016/j.alit.2015.07.007.10.

3. Mertes PM, Malinovsky JM, Jouffroy $L$, the Working Group of the SFAR and SFA and Aberer W, Terreehorst I, Brockow K, et al. Reducing the risk of anaphylaxis during anesthesia: 2011 updated guidelines for clinical practice. J Investig Allergol Clin Immunol. 2011;21(6):442-53.

4. Hopkins PM, Cooke PJ, Clarke RC, Guttormsen AB, Platt PR, Dewachter P, et al. Consensus clinical scoring for suspected perioperative immediate hypersensitivity reactions. Br J Anaesth. 2019;123(1):e29-37. https://doi.org/1 0.1016/j.bja.2019.02.029.

5. Valent P, Bonadonna P, Hartmann K, Broesby-Olsen S, Brockow K, Butterfield $\mathrm{JH}$, et al. Why the $20 \%+2$ tryptase formula is a diagnostic gold standard for severe systemic mast cell activation and mast cell activation syndrome. Int Arch Allergy Immunol. 2019;180(1):44-51. https://doi.org/10.1159/000501 079.

\section{Publisher's Note}

Springer Nature remains neutral with regard to jurisdictional claims in published maps and institutional affiliations.

\section{Submit your manuscript to a SpringerOpen ${ }^{\circ}$ journal and benefit from:}

- Convenient online submission

- Rigorous peer review

- Open access: articles freely available online

- High visibility within the field

- Retaining the copyright to your article 